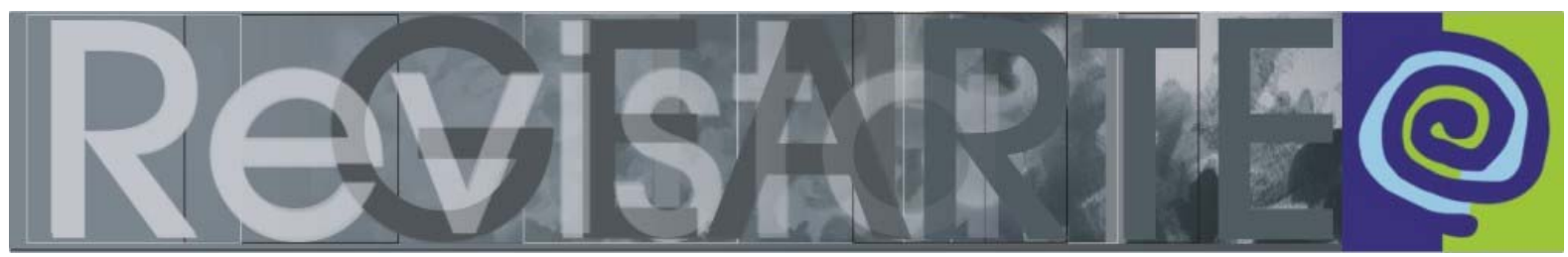

ISSN 2357-9854

\title{
Ensaio visual: \\ Escolinha de Arte de São Paulo: março de 1968 a junho de 1971 Segundo capítulo: Situação/estímulo aberta
}

\author{
Ana Mae Barbosa (USP e UAM - Brasil) \\ Sidiney Peterson Ferreira de Lima (Pesquisador independente - Brasil)
}

\begin{abstract}
RESUMO
No primeiro capítulo, intitulado Escolinha de Arte de São Paulo: sequencialidade ${ }^{1}$, mostramos a preocupação em estender o interesse da criança pelo seu próprio trabalho, desenvolvendo a tenacidade de buscar a forma adequada para expressar as suas ideias, experimentadas em vários e repetidos desenhos, até os próprios alunos considerarem satisfeitos os seus objetivos. No segundo capítulo ${ }^{2}$, apresentamos propostas de trabalho na Escolinha de Arte de São Paulo, nascidas da necessidade de melhorar e desesteriotipar a expressão da criança, bem como provocar novas construções visuais, a partir da realidade circundante. Com a ideia de conscientização sempre presente, já operávamos com o conceito de arte expandido para diferentes mídias visuais. O trabalho com televisão será objeto do terceiro e último capítulo.
\end{abstract}

PALAVRAS-CHAVE

Design. Moda. Abstração.

\section{ABSTRACT}

The first chapter entitled Little School of Art of São Paulo: sequentiality, shows the concern in extending the child's interest in their own work, developing the tenacity to seek the appropriate way to express their ideas, tried in various and repeated drawings till the students themselves considered their goals satisfied. In this second chapter, we present propositions for work in Little School of Art of São Paulo, based on the needs to improve and the child's expression avoiding stereotypes. The other aim was to provoke new visual constructions from the observation of surrounding realities. With the ever-present idea of Conscientization we operated the concept of expanded art towards different visual media. The third and final chapter will be about the work on television.

\section{KEYWORDS}

Design. Fashion. Abstraction.

A "situação/estímulo aberta", na Escolinha de Arte de São Paulo (EASP), era fundamentada no pensamento de Umberto Eco (Obra Aberta). É equivalente nos anos de 1920 ao Centro de Interesse, nos anos 1960 ao Estudo do Meio e, atualmente, à Pedagogia de Projeto. O programa enfatizou três ações:

1 Publicado na Revista GEARTE, v. 2, n. 2, ago. 2015.

2 As imagens apresentadas neste ensaio pertencem ao acervo pessoal de Ana Mae Barbosa. 
desenvolvimento da percepção, da análise focada na abstração e da capacidade crítica.

Situação/estímulo 1: Detectada a dificuldade de crianças e jovens representarem movimentos em seus desenhos, foram levados ao Jóquei Club de São Paulo, para que observassem e desenhassem as diferentes movimentações dos cavalos.

"Queríamos levar as crianças para observar esses movimentos, com a finalidade de trazer movimentação ao seu desenho. Ter a experiência desses movimentos e aí desenhar. Era isso que nós desejávamos, mas jamais dando tema. Nunca foi dado um tema na Escolinha, isso é fundamental, nunca foi dado tema, nós provocávamos a experimentação"3.

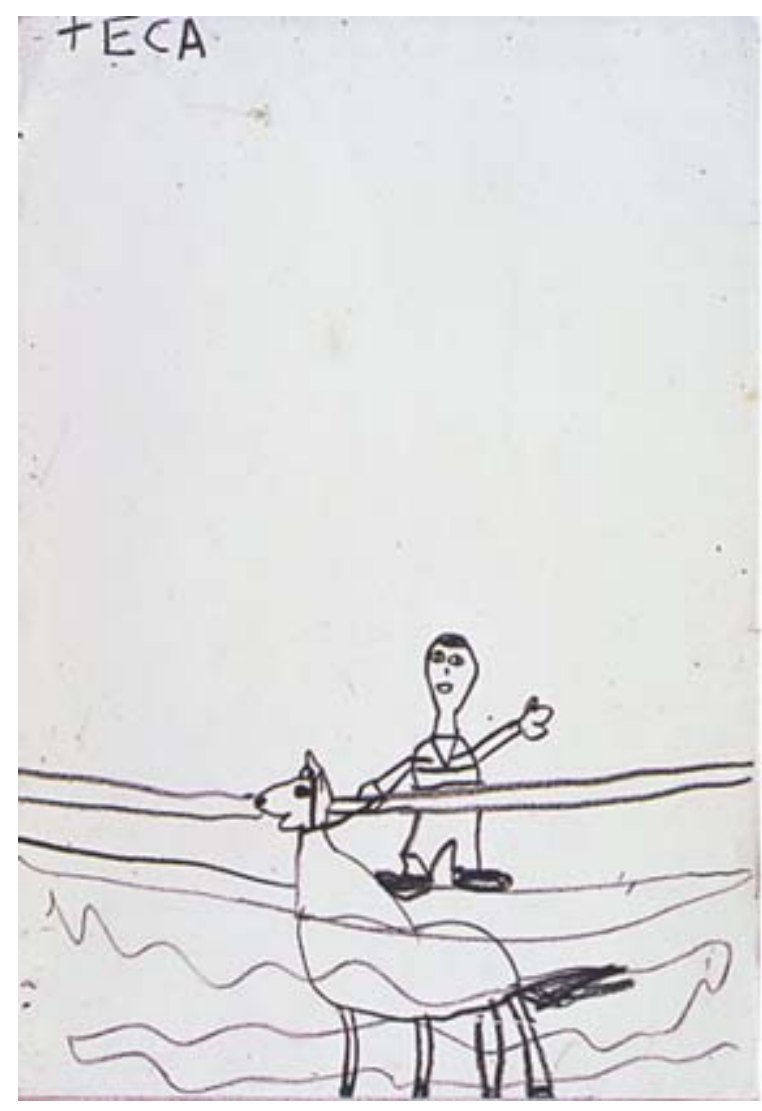

Cavalos se exercitando na piscina do Jóquei Club de São Paulo.

3 Trecho de entrevista com a arte/educadora Ana Mae Barbosa In: LIMA, Sidiney Peterson F. de. Escolinha de Arte de São Paulo: instantes de uma história. Dissertação de mestrado. UNESP. 2014. 

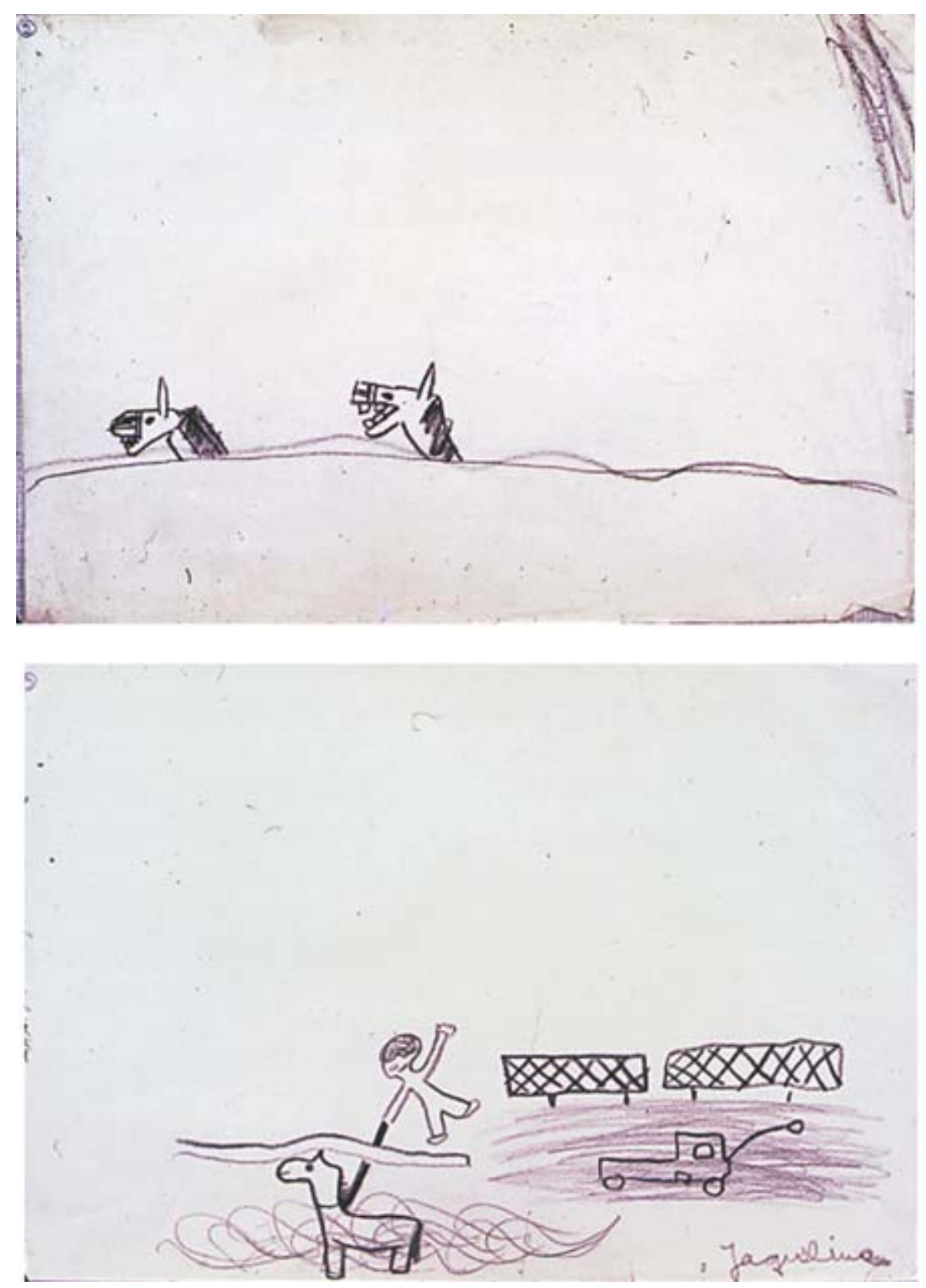

Cavalos se exercitando na piscina do Jóquei Club de São Paulo. 


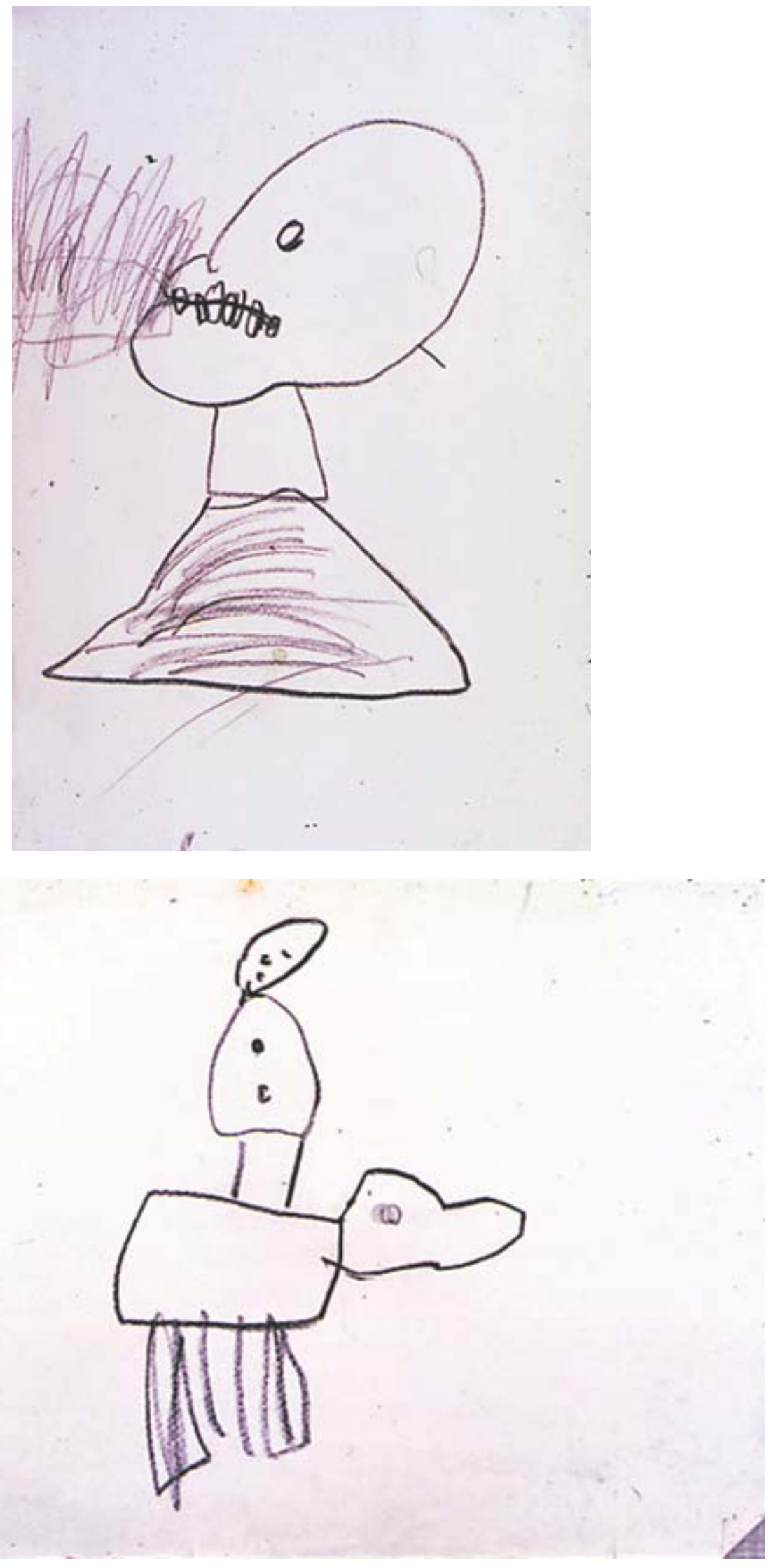

Desenho de crianças de quatro anos. 


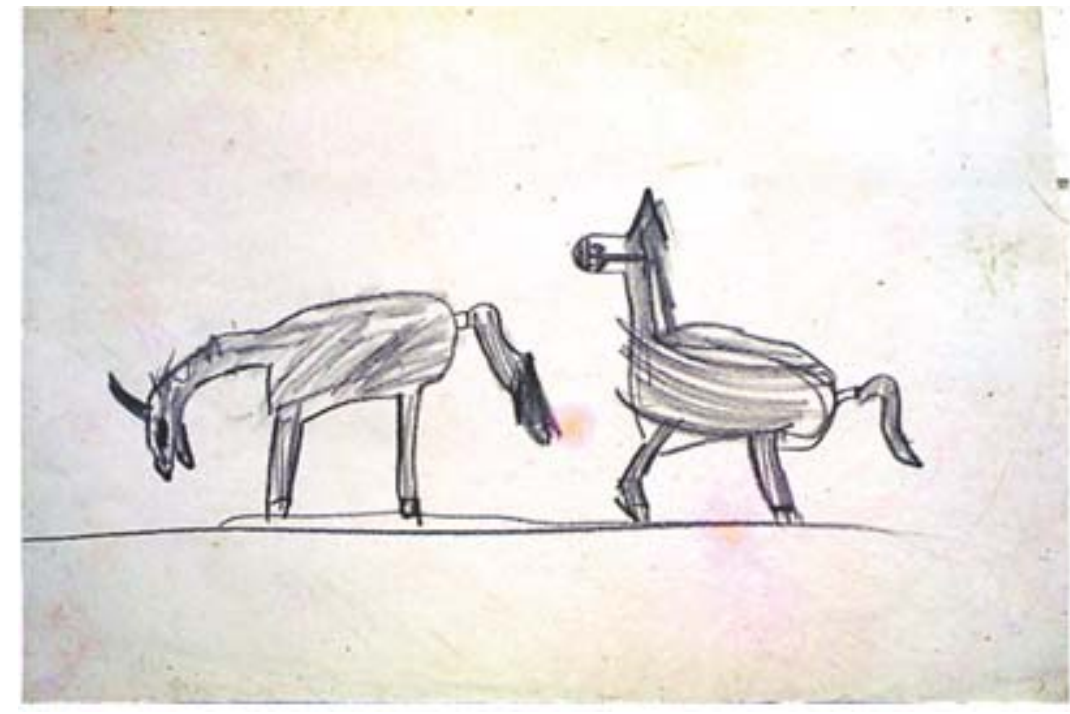

Movimentos nas figuras dos cavalos

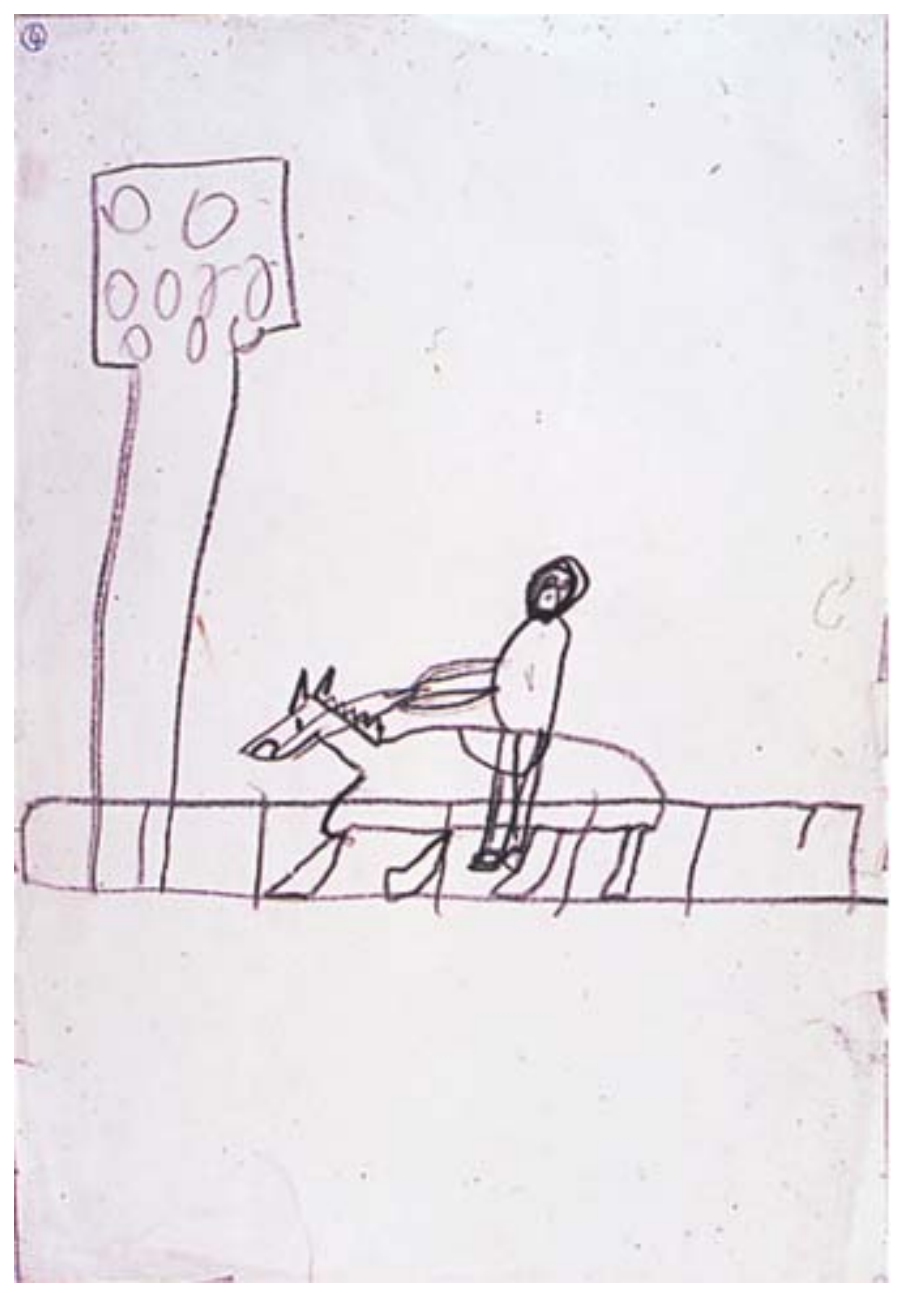




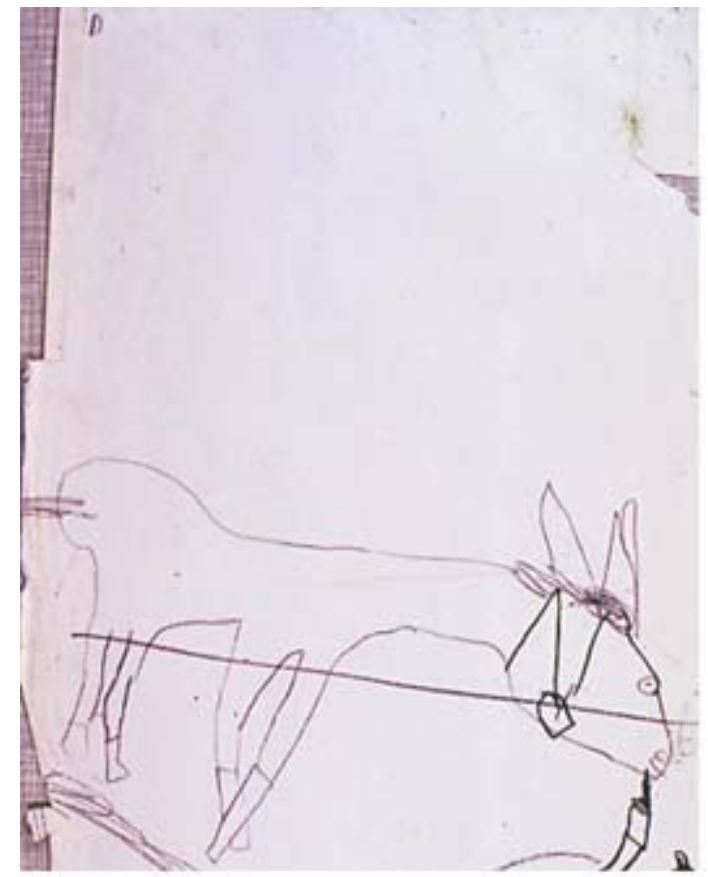

Três diferentes momentos de observação em um único desenho
Movimento em relação ao espaço

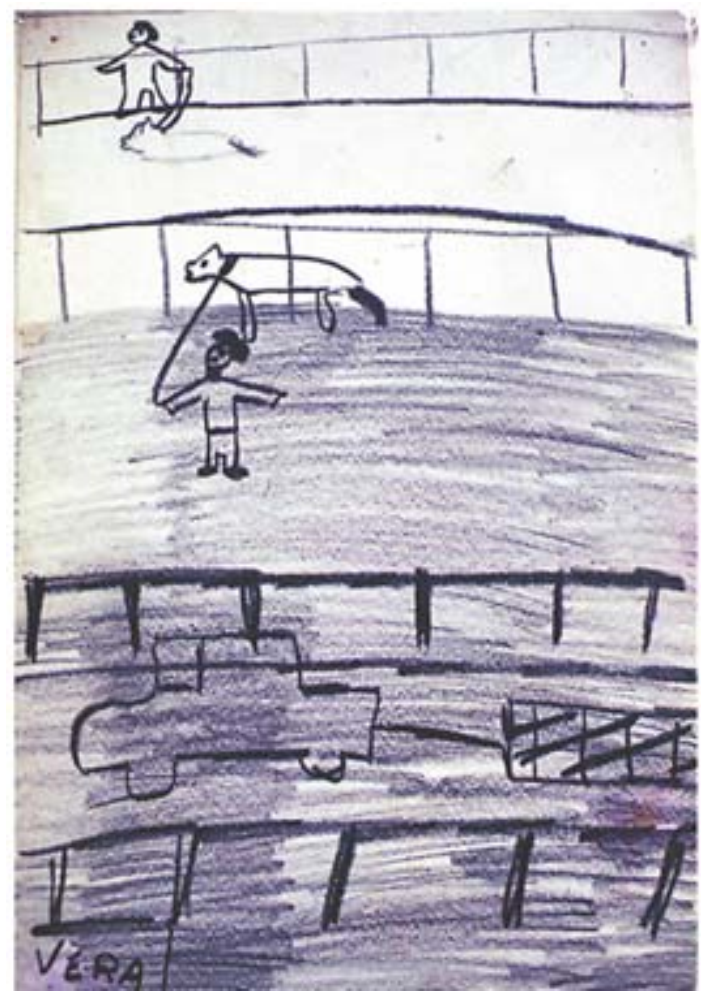



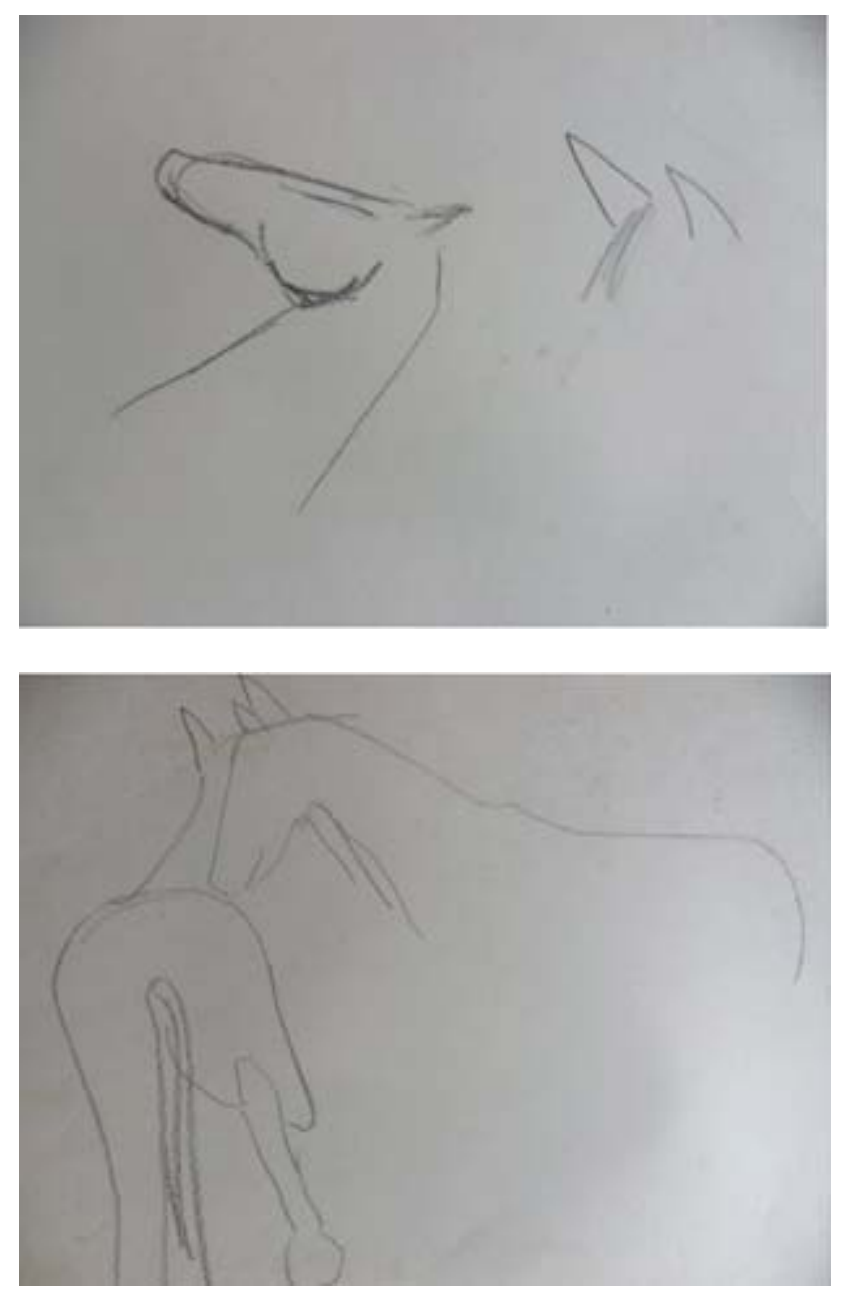

Esboços de movimentos.

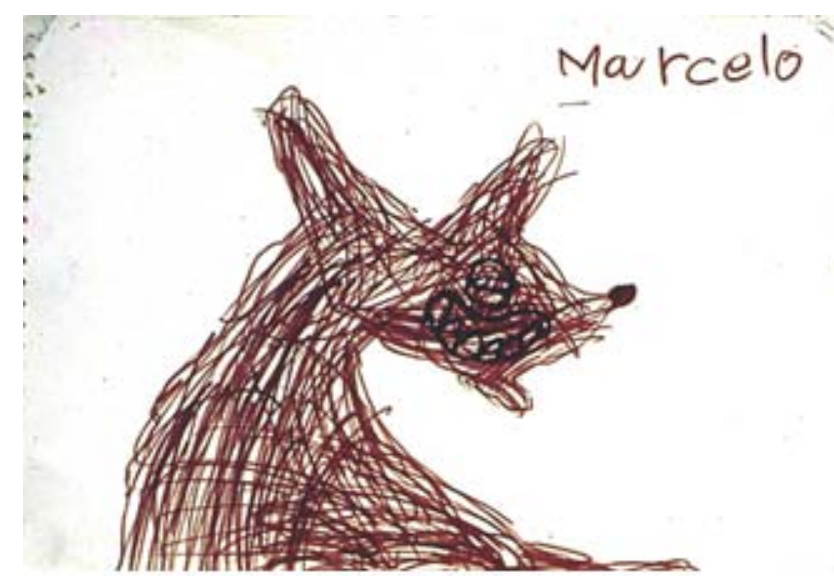

Movimentação da figura e do traço

Vivíamos na época da ditadura militar. Paulo Freire, no exílio em Genéve, dialogava e nos orientava. Nossa preocupação social nos levou a orientar as 
crianças no sentido de fazer entrevistas com os tratadores de cavalos e gestores do Jóquei Club de São Paulo. Duas coisas impressionaram as crianças: o fato de os cavalos comerem verduras e legumes e o alto preço para manter um cavalo no Jóquei Club em relação ao baixo salário do tratador dos animais.

Situação/estímulo 2: Visita a uma fábrica de papel para observação do movimento das máquinas e da transformação do material.
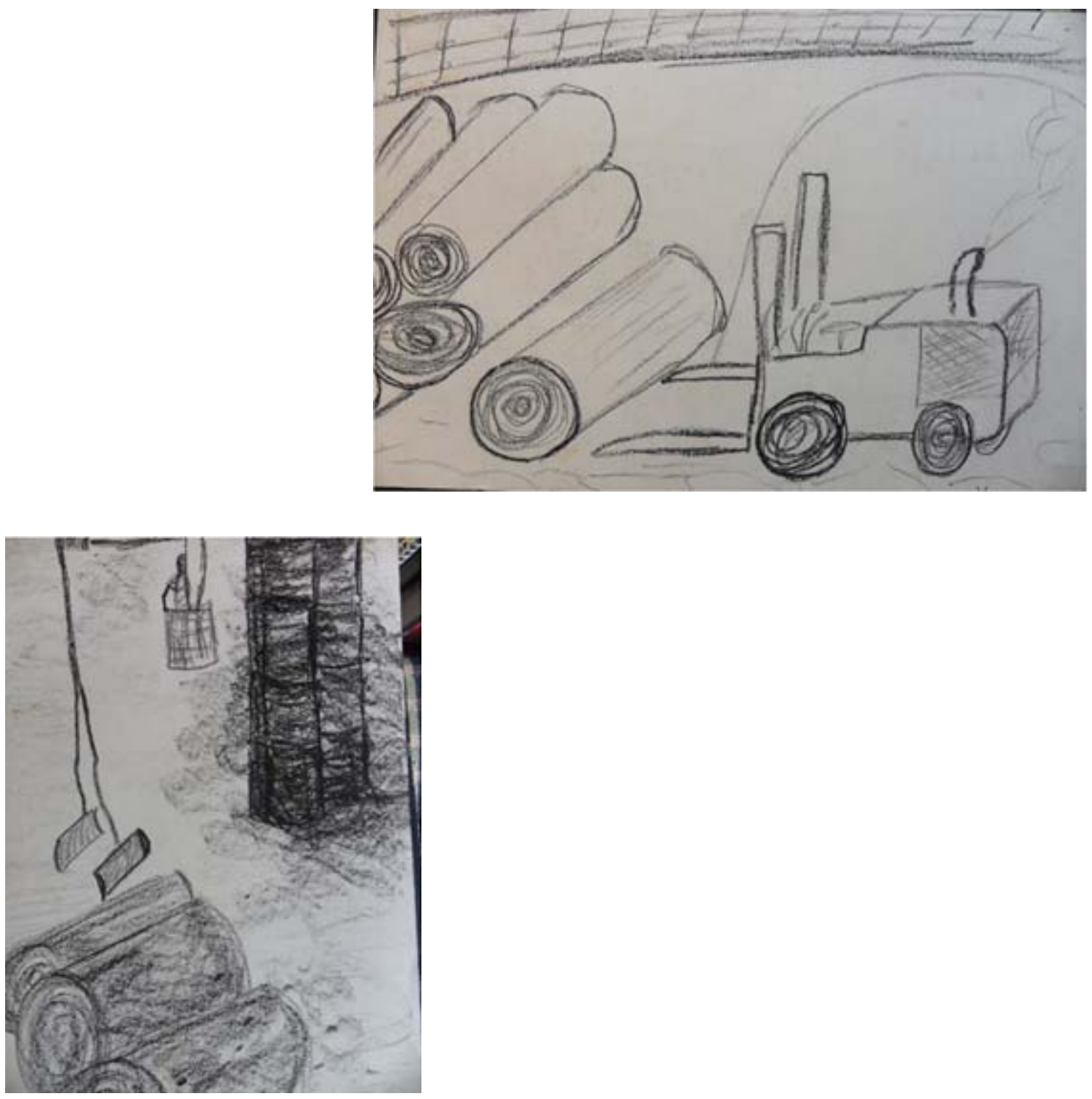


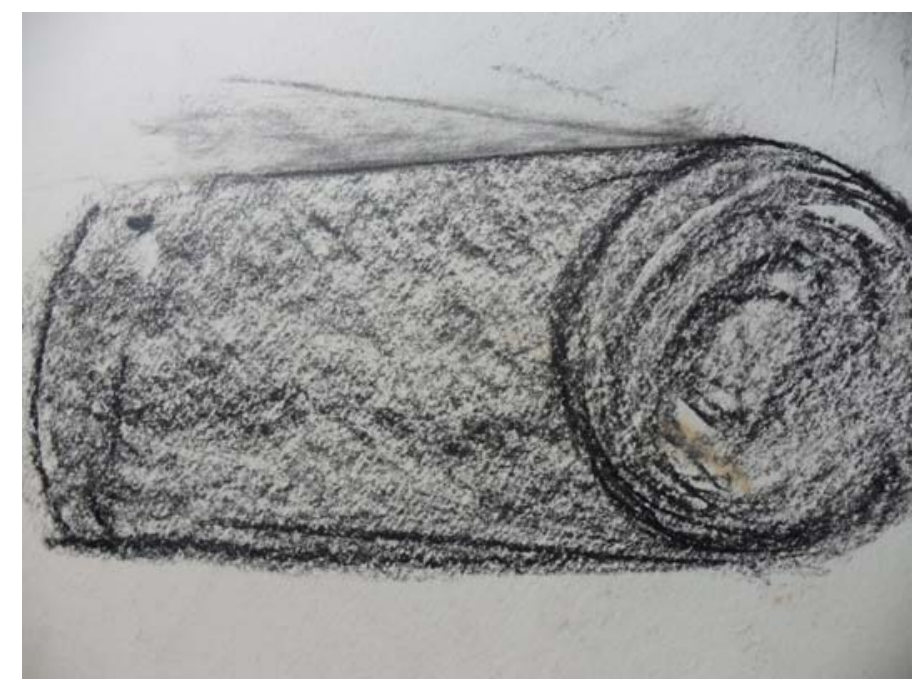

As ações desenvolvidas nessa atividade tinham, também, como objetivos conhecer a origem dos materiais com os quais a criança trabalhava e dar consciência acerca das transformações desses materiais, até chegar à sua função de uso. Para Célia Cymbalista, "o foco era esse, nós estávamos trabalhando observação para desenvolver a capacidade crítica, esse era o foco $4 . "$

Situação/estímulo 3: Visita à Editora Abril para observar a produção da Revista Recreio, única publicação voltada para o público infantil editada no Brasil, naquela época, e a produção de revistas em quadrinhos (que eram traduções de produções norte-americanas).

\begin{abstract}
Uma das crianças trouxe a discussão referente à diagramação, da expressão, dos detalhes fisionômicos de cada situação do quadrinho, então, a criança trouxe essa discussão e estava muito interessada. Naquele tempo era muito forte a coisa de negar a história em quadrinhos por causa do pensamento expressivo, porque se acreditava que desfocava a criança. Era proibido. Tinham famílias que proibiam a leitura das histórias em quadrinhos porque não era literatura, coisas do gênero. Nós tínhamos um pensamento contrário a tudo isso, nós partíamos do seguinte, se era significativo para uma criança é porque tem coisa ali e nós íamos buscar essa coisa ${ }^{5}$.
\end{abstract}

4 LIMA, Sidiney Peterson F. de. Escolinha de Arte de São Paulo: instantes de uma história. Dissertação de mestrado. UNESP. 2014.

5 Idem. 

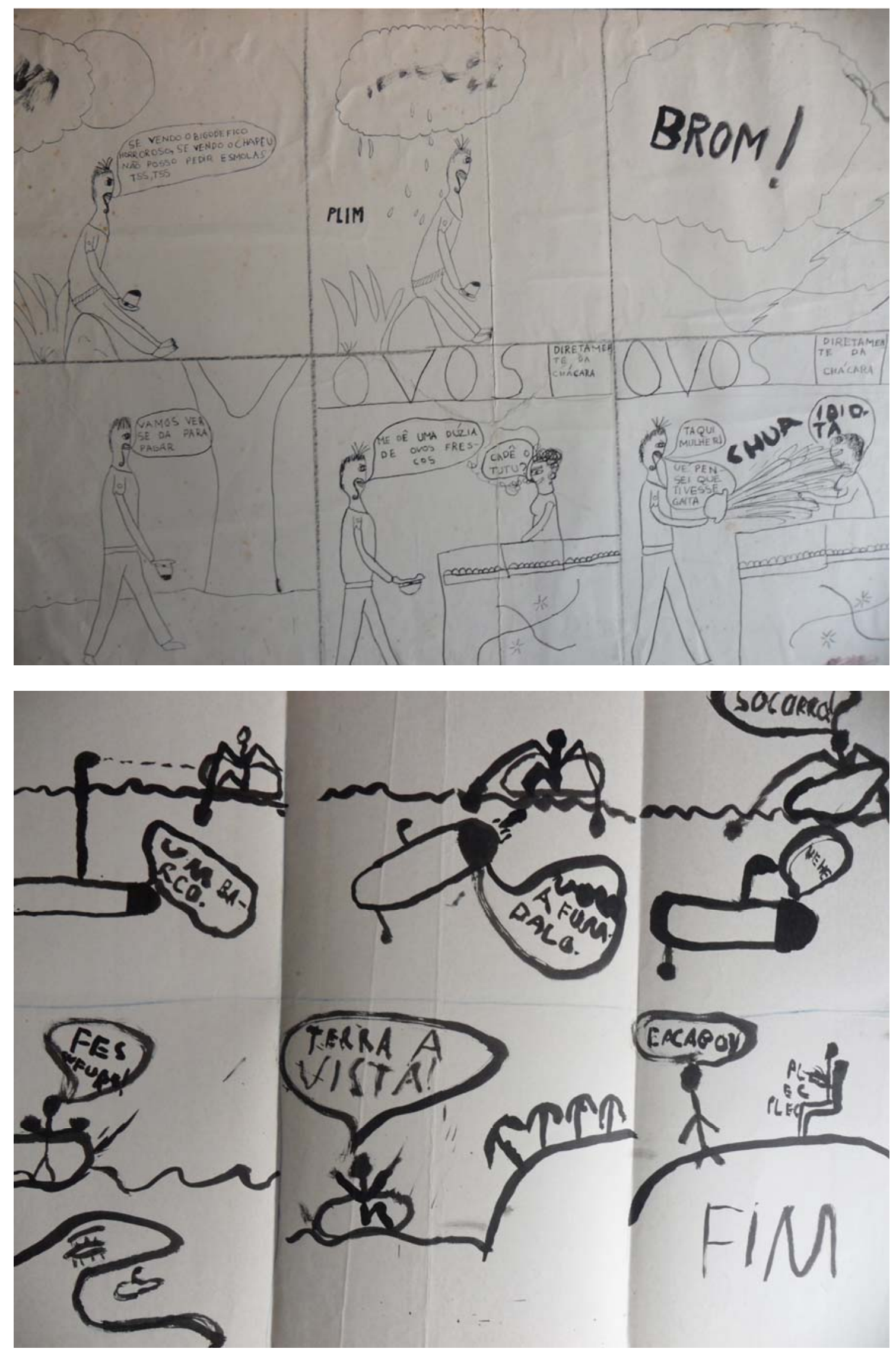
Situação/estímulo 4: Visita a uma loja de objetos de design para casa. A proposta era que cada dois alunos observassem um objeto e procurassem desenhá-lo de forma a adaptá-lo à sua casa ou de forma a demonstrar as qualidades do objeto.

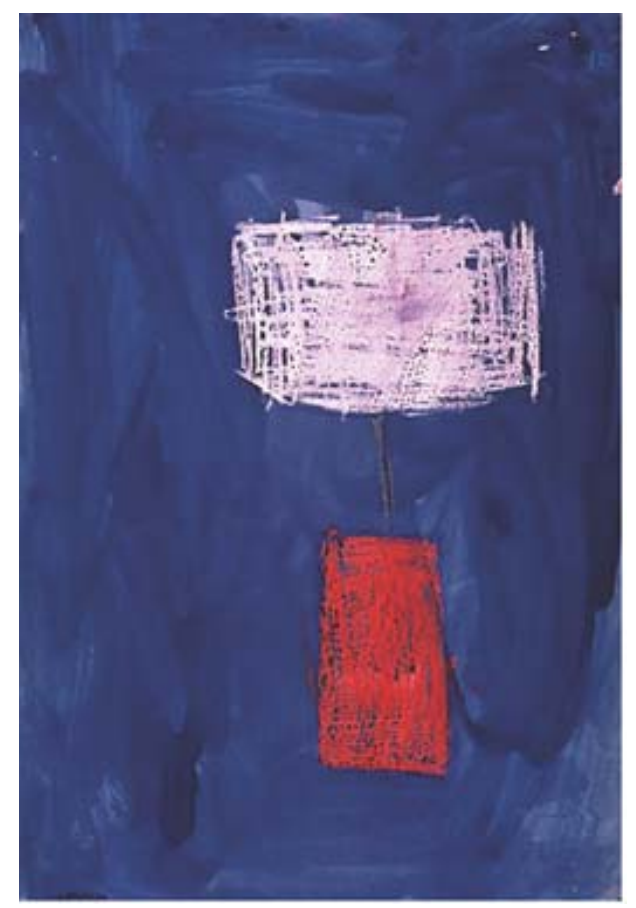

Representação realística do abajur

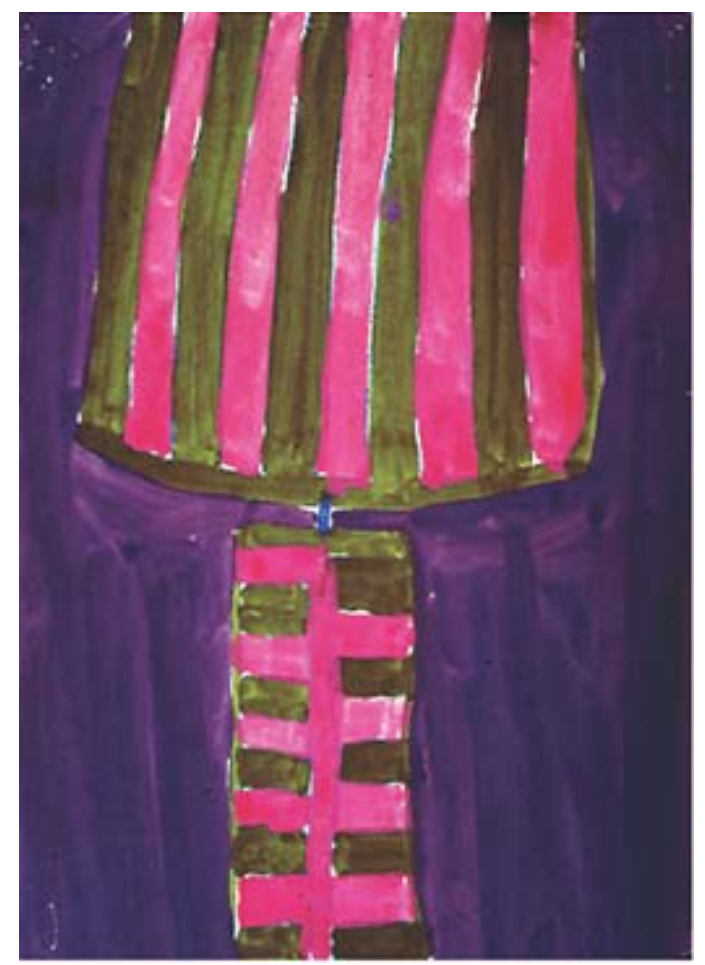

Abajur adaptado ao quarto da aluna 
Desenho do lustre salientando a qualidade de decorativismo

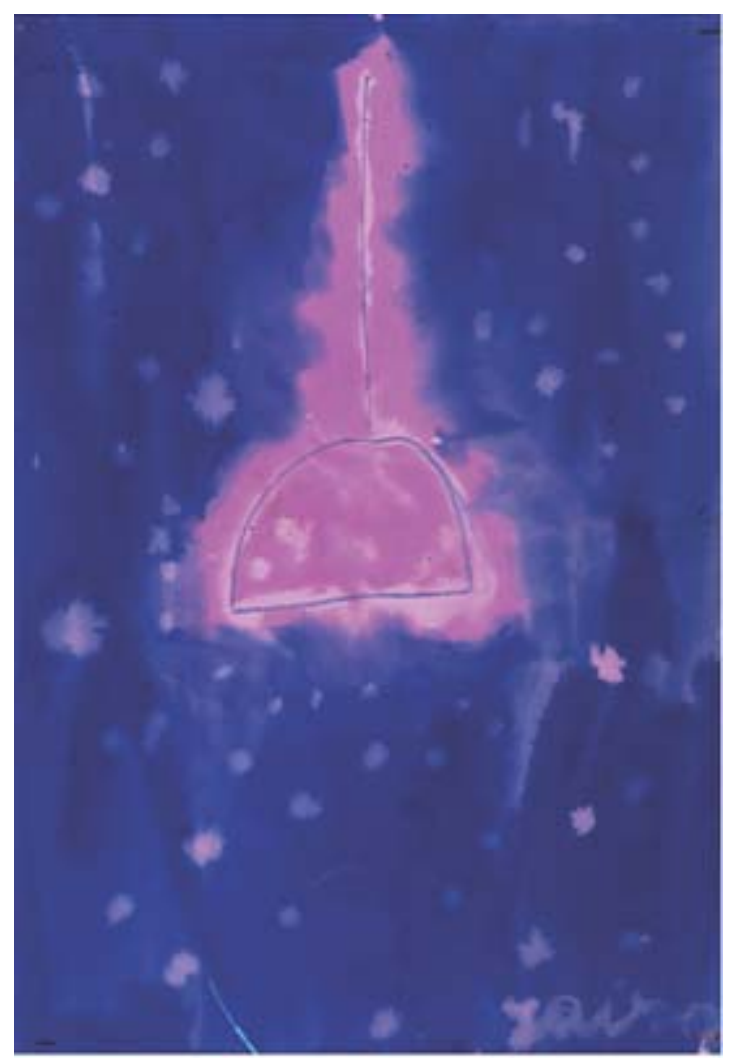

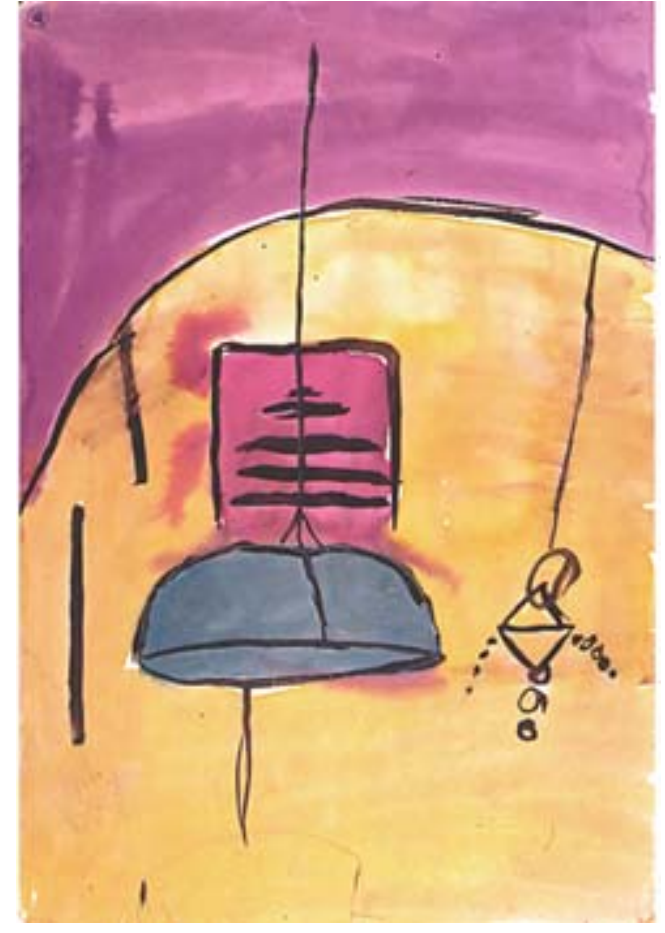

Desenho do lustre salientando a luminosidade 
Desenho de vários objetos no mesmo papel. Observar a garrafa vista de outra maneira pelo aluno que produziu o desenho abaixo
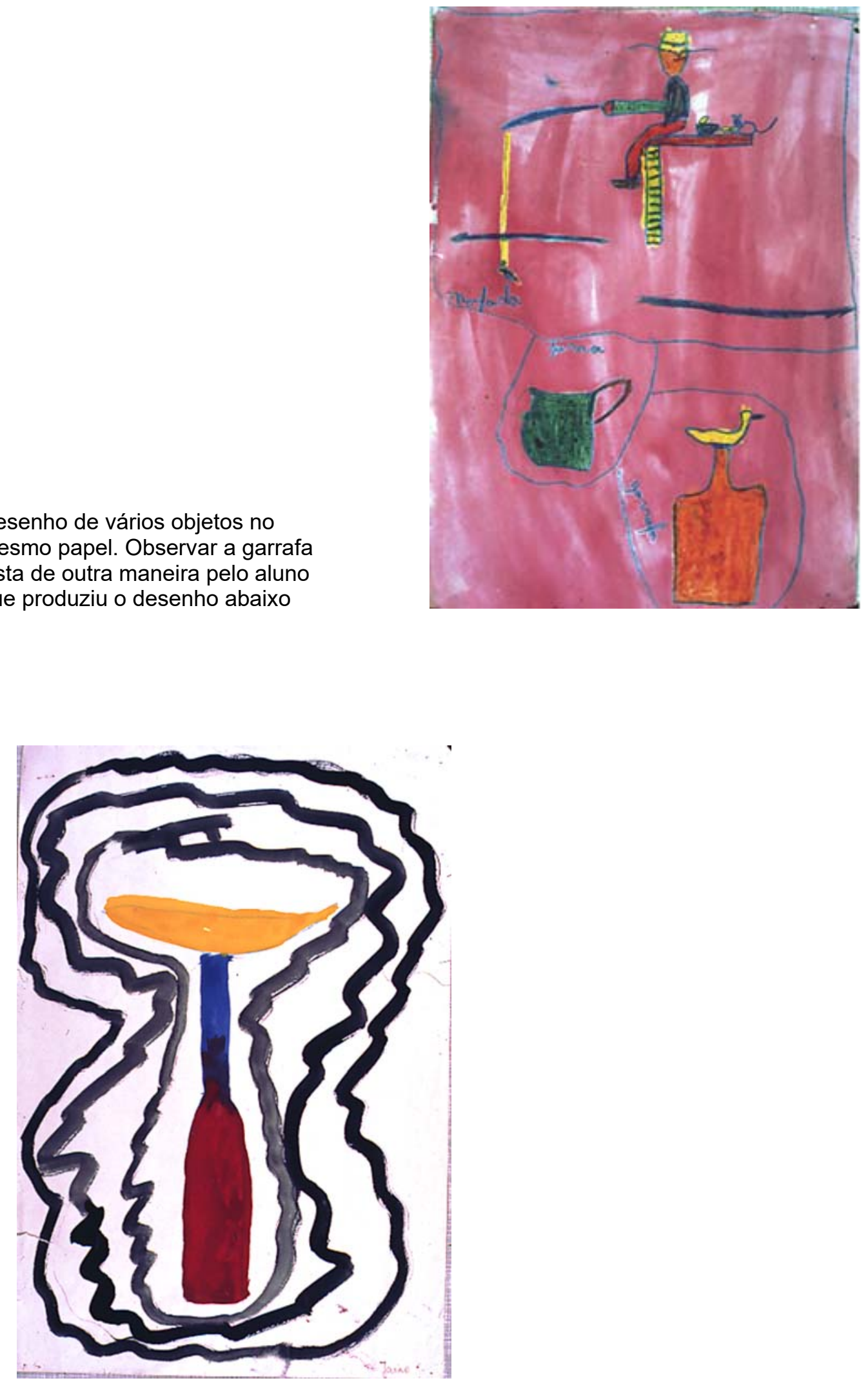
Dois alunos que, contrariando a proposta de desenhar o mesmo objeto, desenharam dois objetos diferentes, porém da mesma categoria: tábua de frios.
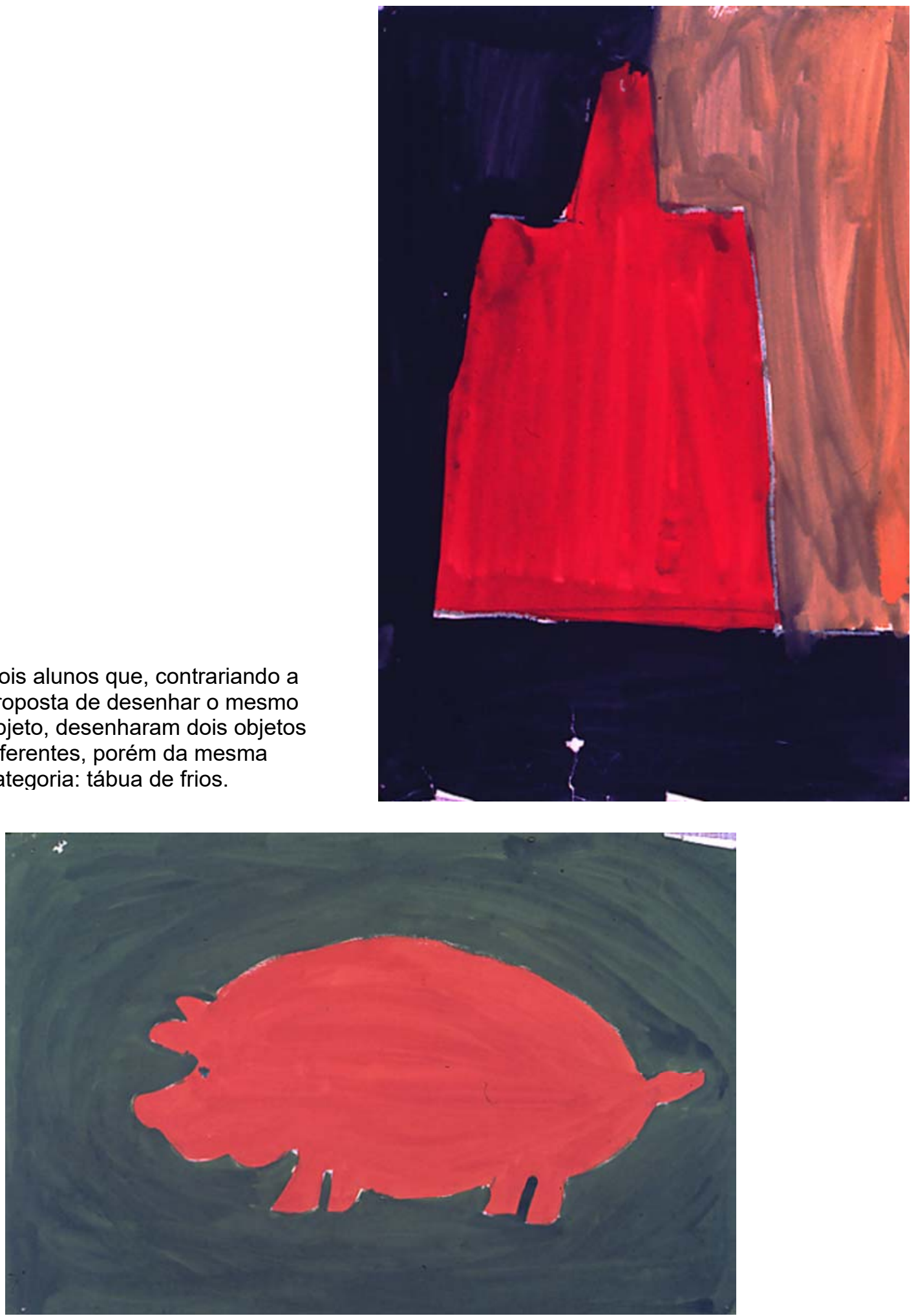
Aluno que trabalhou sozinho. Sua mãe era cozinheira.

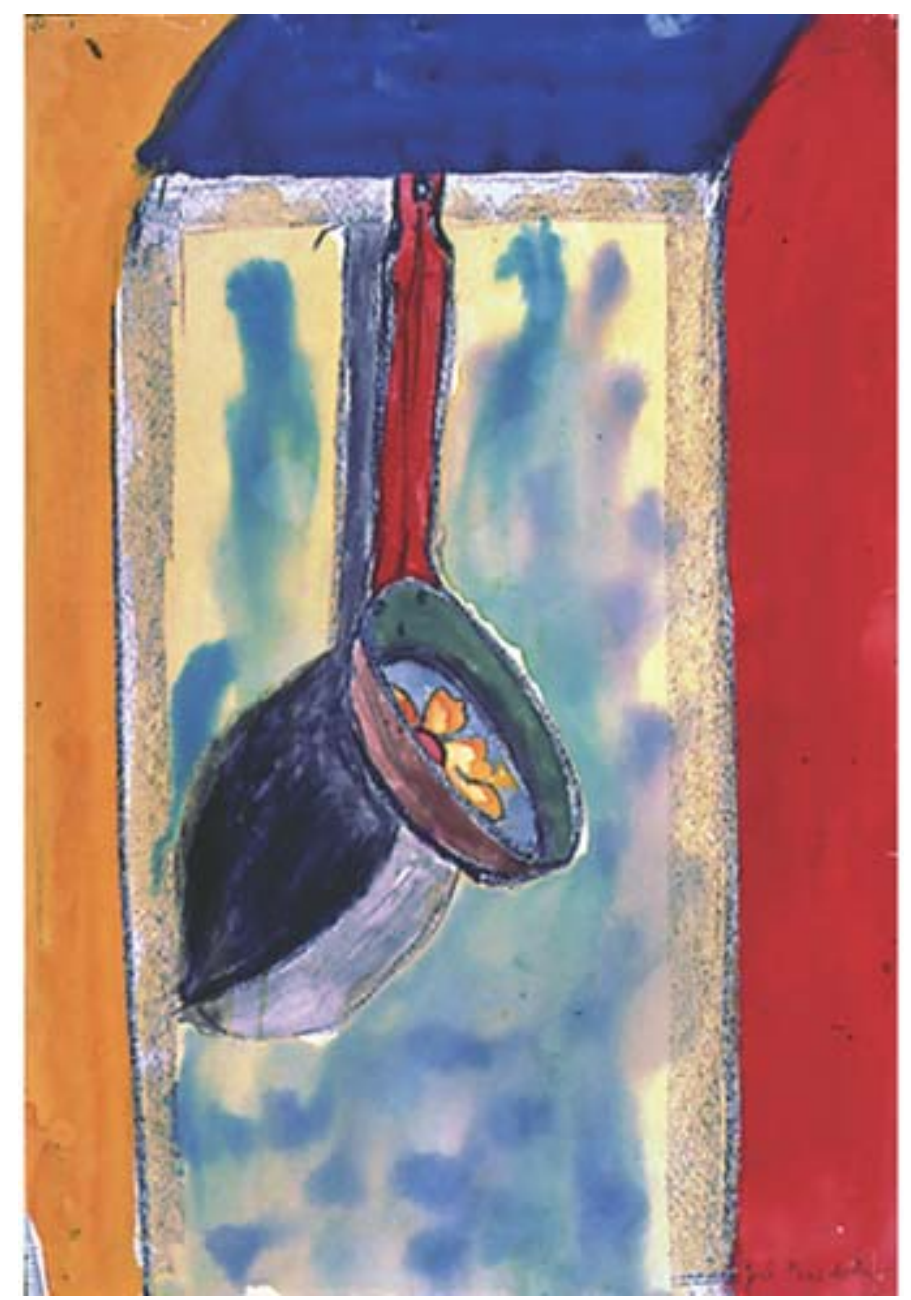

Situação/estímulo 5: Visita à Rua Augusta para observar a moda apresentada nas lojas e pelos transeuntes na rua. 

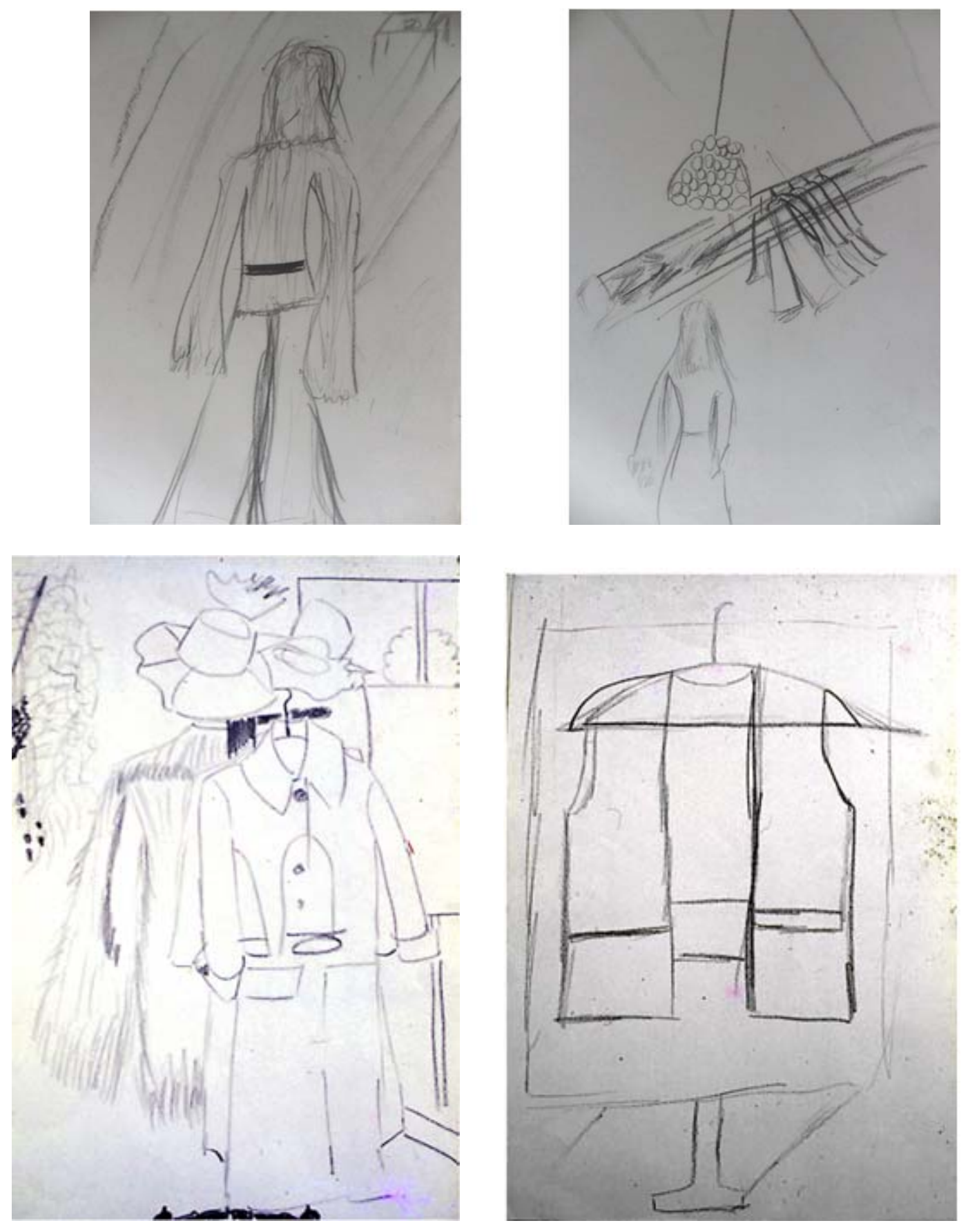


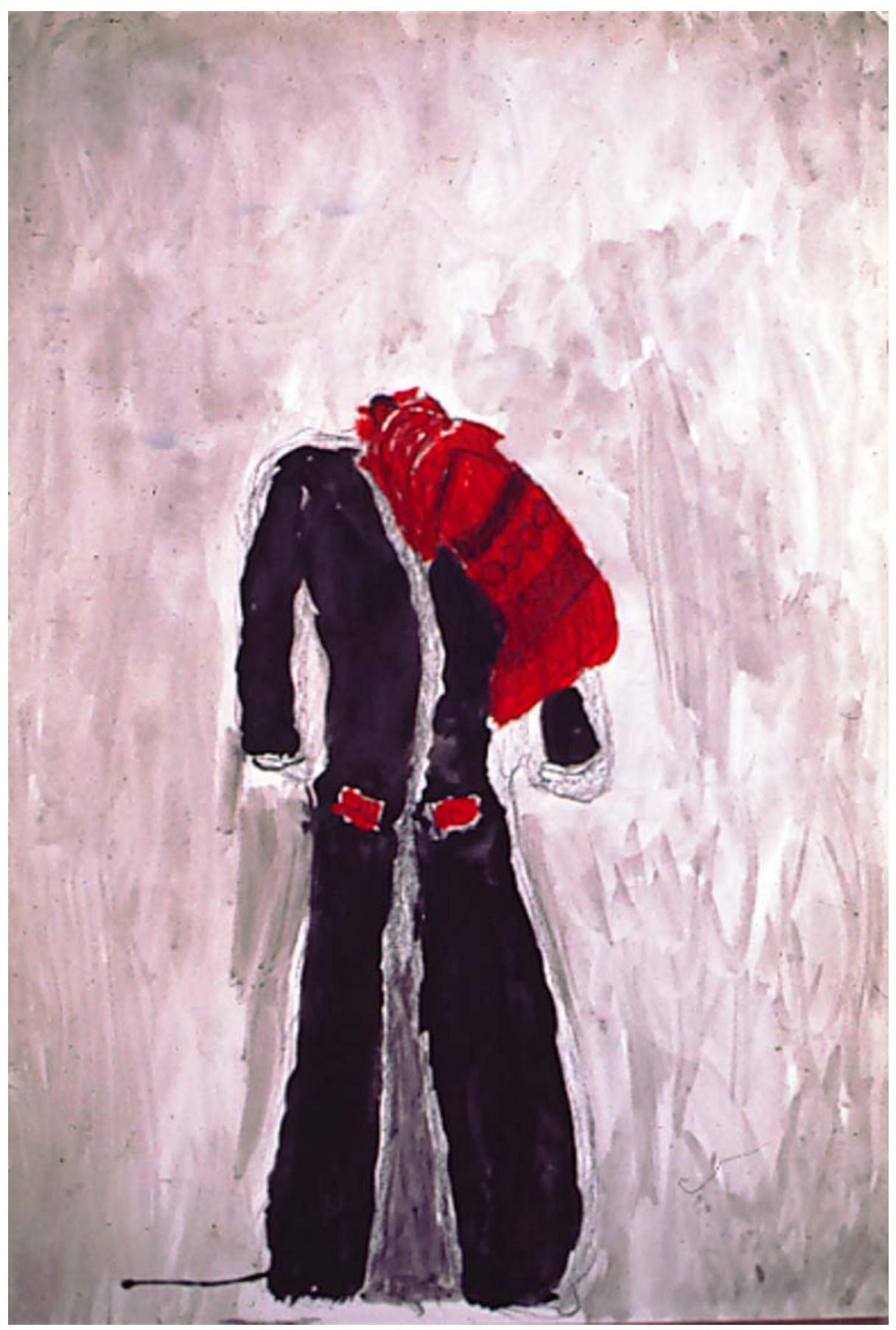


Situação/estímulo 6: Exercício de abstração.

6.1: Do figurativo ao resultado abstrato

Observação da tartaruga que havia na Escolinha, com proposta de desenhar o papel como se fosse um casco da tartaruga. Todos os resultados pareciam abstratos e foi discutida com os alunos a abstração.
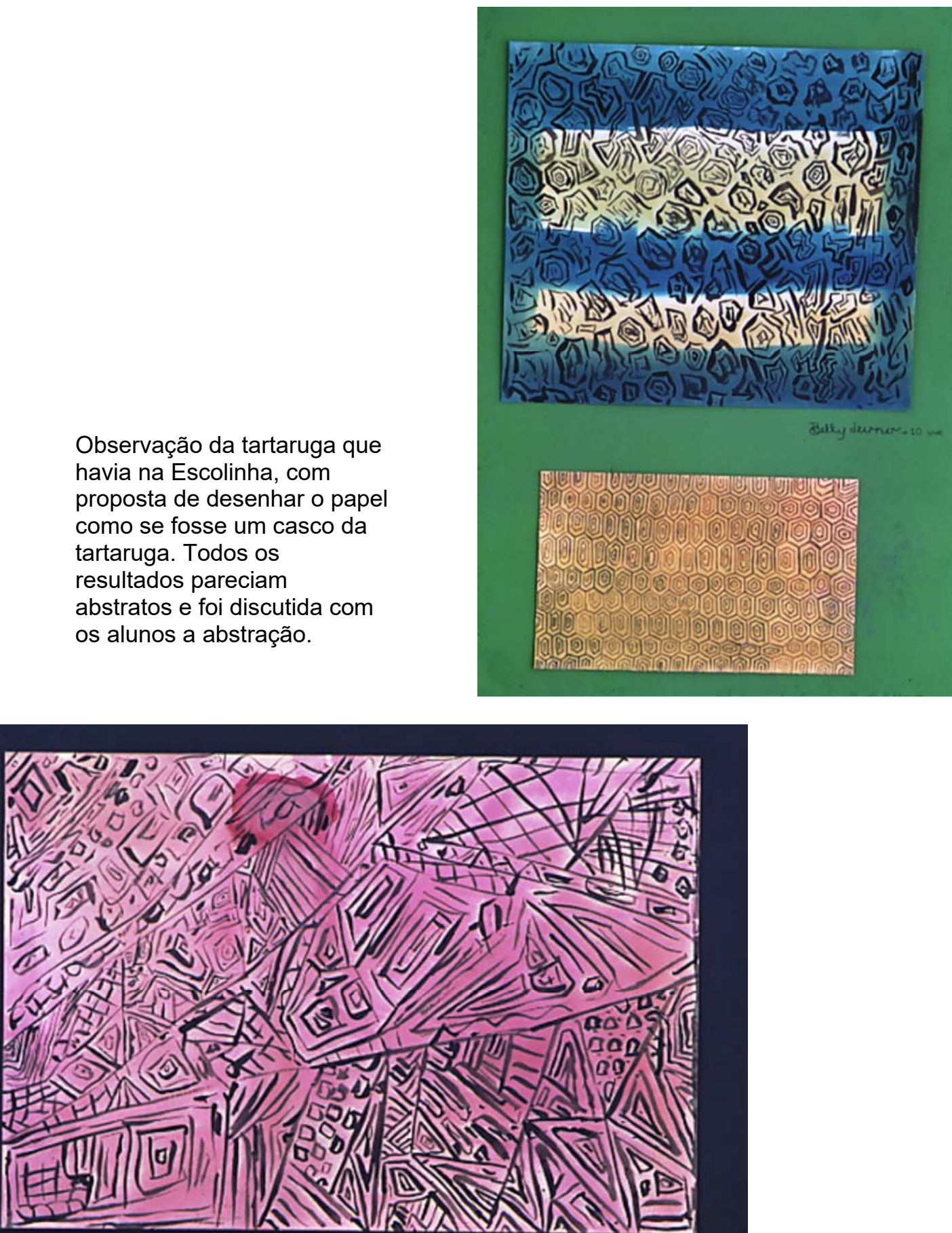
6.2. Observação da arquitetura da Escolinha, do jardim da Escolinha e do meio ambiente, em geral, tentando abstrair a figura e traçar as linhas essenciais que constroem a visualidade do objeto.

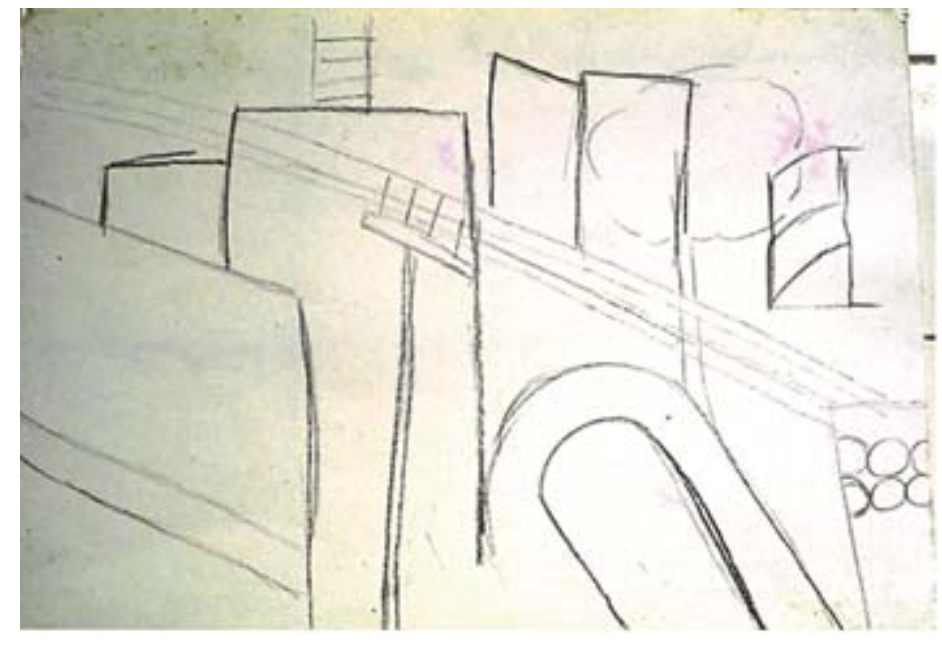

Da simplificação a abstração
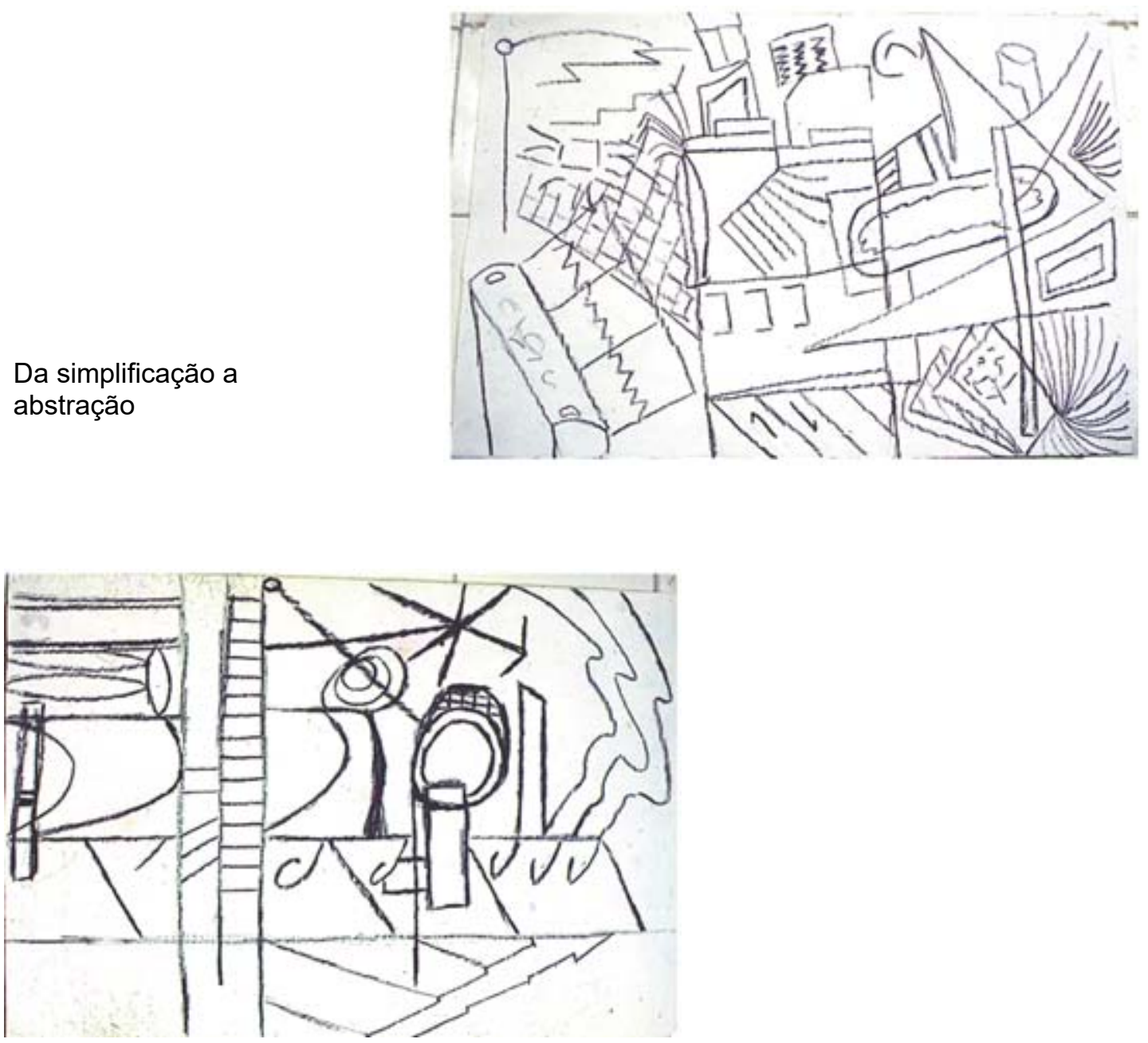
Situação/estímulo 7: Exploração de diferentes materiais, luz e sombra.
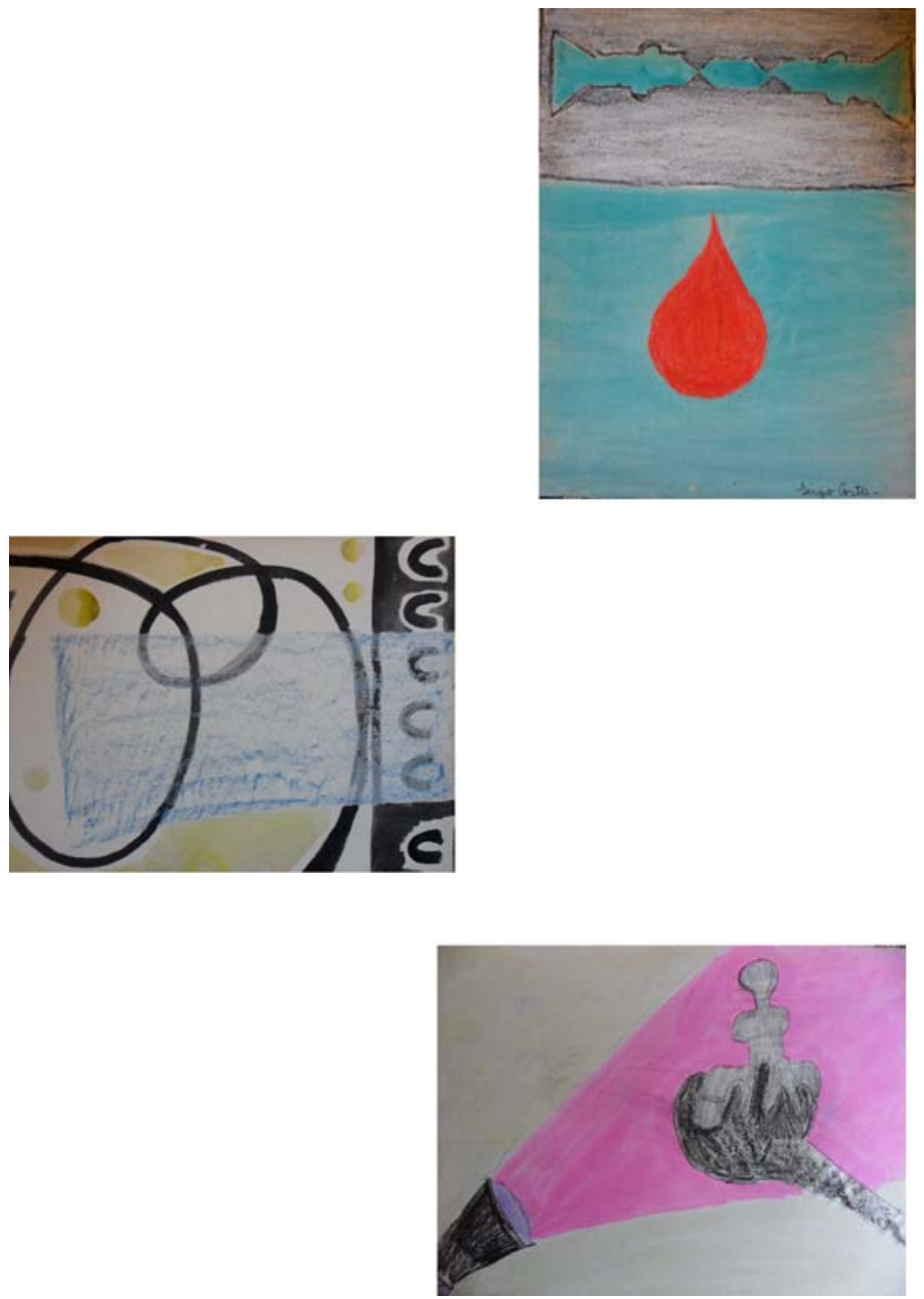


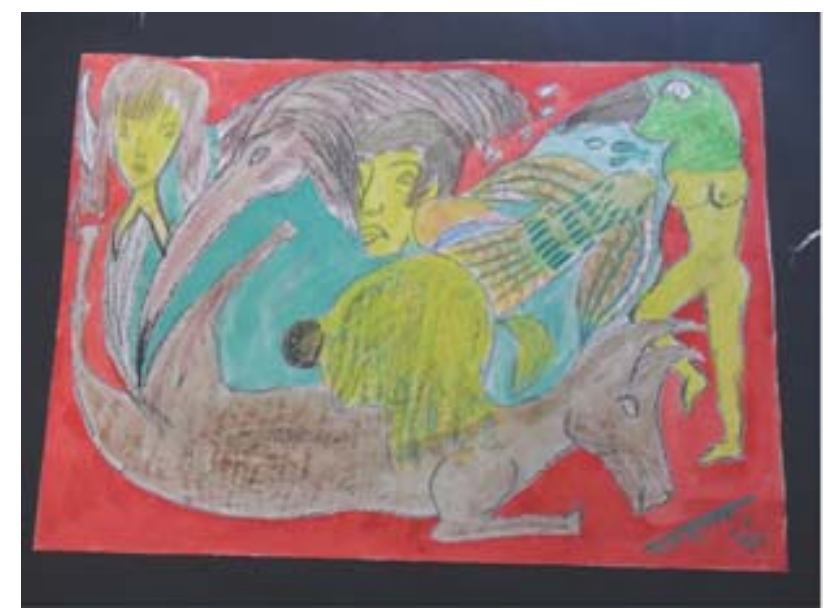

Uso do fogo para queimar a abertura pintada de vermelho

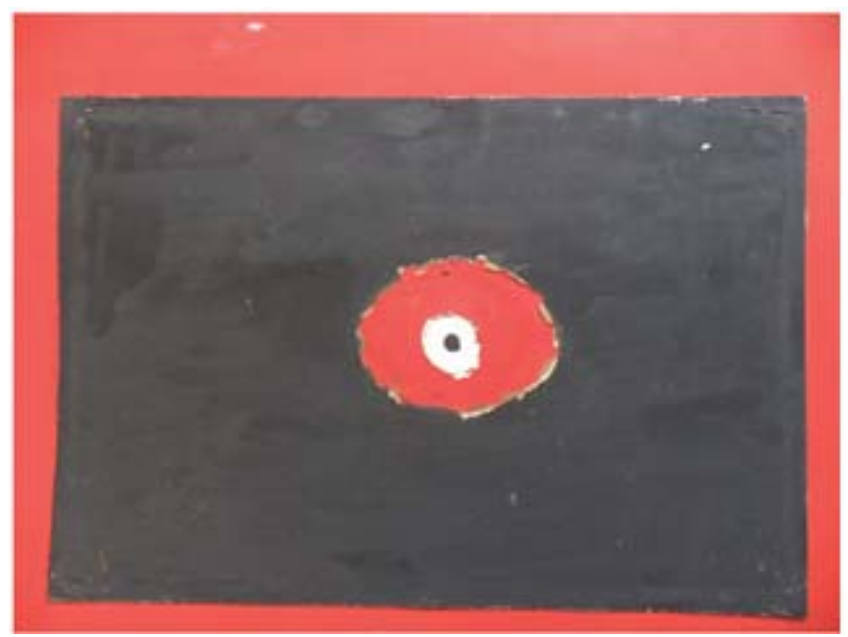

Situação/estímulo 8: ver revistas e jornais, discutir os problemas veiculados e fazer colagens que representassem uma crítica.

"Foi a partir da leitura de imagens, presentes nos jornais e nas revistas, que surgiu a proposta dos estudantes construírem um trabalho que representasse uma crítica dos estudantes ao mundo, ao que leram e ao que viram. Com essas atividades, propúnhamos o uso de imagens prontas em outro contexto que era transformado pelas crianças, que recortavam imagens da revista e do jornal e criavam com elas as suas próprias narrativa $6 . "$

6 LIMA, Sidiney Peterson F. de. Escolinha de Arte de São Paulo: instantes de uma história. Dissertação de mestrado. UNESP. 2014. 

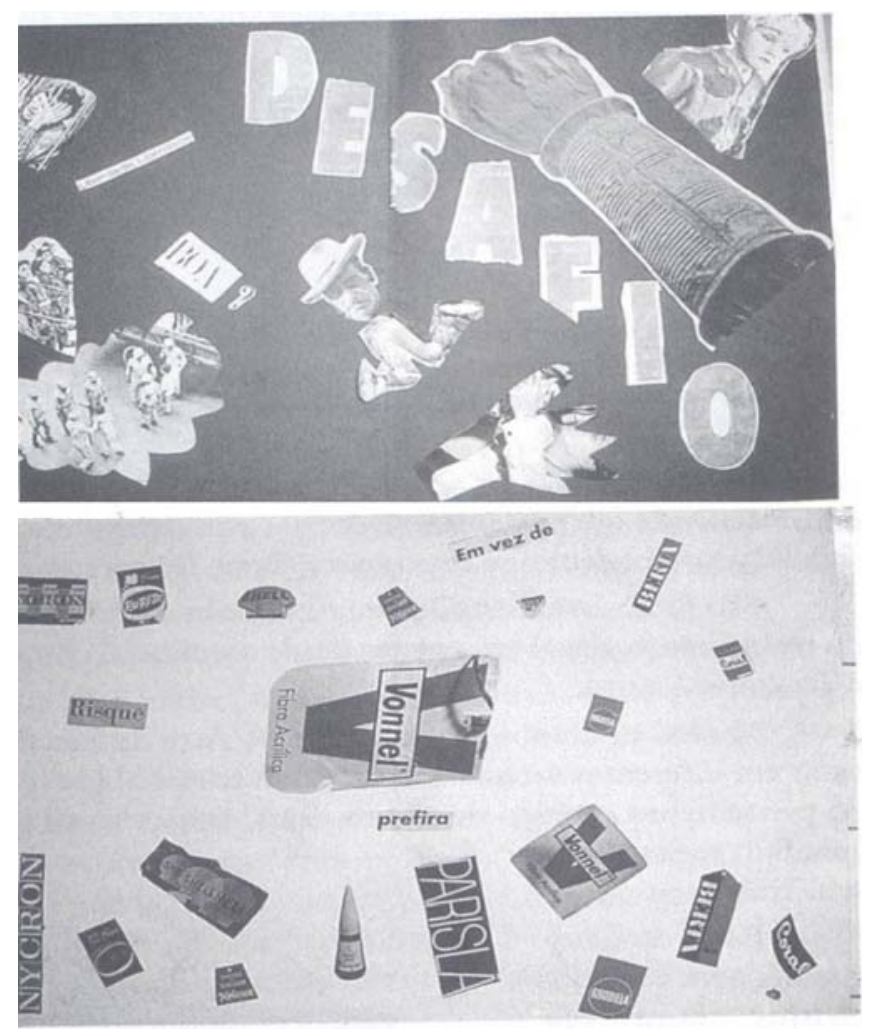

\section{Referências}

BARBOSA, Ana Mae. Teoria e Prática da Educação Artística. São Paulo, Cultrix. 1975.

LIMA, Sidiney Peterson F. Escolinha de Arte de São Paulo: instantes de uma história. 2014. Dissertação (Mestrado em Artes) - Instituto de Artes, Universidade Estadual Paulista/UNESP, São Paulo. 2014.

\section{Ana Mae Barbosa}

Possui graduação em Direito pela Universidade Federal de Pernambuco (1960), mestrado em Art Education pela Southern Connecticut State College (1974) e doutorado em Humanistic Education pela Boston University (1978). Atualmente é Professora Titular aposentada da Universidade de São Paulo e professora da Universidade Anhembi Morumbi. Foi presidente da International Society for Education through Art (InSEA), da Associação Nacional de Pesquisadores em Artes Plásticas (ANPAP) e diretora do Museu de Arte Contemporânea da USP. Tem livros e artigos publicados em diversos países. Tem experiência na área de Artes, com ênfase em Arte/Educação, atuando principalmente nos seguintes temas: Ensino da Arte e contextos metodológicos, História do Ensino da Arte e do Desenho, Ensino do Design, Administração de Arte, Multiculturalidade, Estudos de Museus de Arte e Estudos Visuais.

E-mail: anamaebarbosa@gmail.com

Currículo: http://lattes.cnpq.br/1650414096296319

\section{Sidiney Peterson Ferreira de Lima}

Possui graduação em Pedagogia pela Universidade Federal Rural de Pernambuco (UFRPE, 2010), mestrado em Artes pela Universidade Estadual Paulista (UNESP, 2014). Experiência na área de Educação, Educação em Museus e Mediação Cultural. Tem desenvolvido pesquisas com foco na história do ensino de artes e na formação de arte/educadores no Brasil.

E-mail: sidney.peterson@gmail.com

Currículo: http://lattes.cnpq.br/7897838185394600 